\title{
PALABRA VIVA Y ESCRITURA
}

Humberto Giannini Íñiguez 


\section{HUMBERTO GIANNINI ÍÑIGUEZ}

Estudió Hermenéutica y Filosofía de la Religión en la Universidad de Roma. En 1998 fue elegido miembro de número de la Academia Chilena de la Lengua, donde ocupa el sillón $\mathrm{N}^{\circ} 12$. Premio Nacional de Humanidades y Ciencias Sociales 1999, Premio Consejo Nacional del Libro y la Lectura 2008, categoría Ensayo, por La metafísica eres tú y Premio Altazor de Ensayo 2009 por el mismo título. Es académico de la Facultad de Filosofía y Humanidades de la Universidad de Chile. 


\section{PALABRA VIVA Y ESCRITURA}

Así como desde una década a esta parte los celulares han invadido la vida comunitaria, cual invitado que se lleva a todas partes en el bolsillo e interviene con disimulo o sin él en toda reunión privada, interrumpiendo cualquier modo de intimidad, así más o menos se abría en tiempos de Platón la moda del discurso escrito. Platón teatraliza una escena inolvidable para la literatura ${ }^{1}$ y también para la filosofía: la irrupción del discurso escrito en medio del diálogo tradicional.

La escena del Fedro ${ }^{2}$ es la siguiente: Sócrates y su discípulo Fedro se debaten en un diálogo sobre el amor. El maestro no se ha dado cuenta mientras discuten de que Fedro viene preparado para esta discusión trayendo bajo su manto un discurso sobre el tema ya escrito por Lisias, célebre sofista y logógrafo ${ }^{3}$. El joven Fedro piensa con entusiasmo que ese discurso les ayudará ahora a zanjar definitivamente el problema que discuten: a qué tipo de joven amante debe conceder sus favores el amado si quiere conservar su propia independencia.

No nos detendremos a examinar ahora el contenido del discurso escrito por Lisias. Este sería otro tema de discusión. Lo que nos importa es la objeción que hace Sócrates a la escritura misma, en cuanto modo de entrar en un diálogo, y en general, como modo de traspasarse el saber.

La objeción más evidente: el escrito suprime el diálogo; por cuanto este aparece como una pieza oratoria cerrada, a la cual no se le pueden hacer preguntas ni presentar objeciones. El discurso de Lisias es, como al final dirá Sócrates, "un escrito que necesita que le ayuden a sostenerse, puesto que, hecho de letras, no puede defenderse a sí mismo" (Fedro, 275e).

Es evidente: el escrito aparece como una pieza oratoria cerrada, a la cual no se le pueden hacer preguntas ni presentar objeciones. Esto es: suprime el diálogo. Es más: oculta al autor del discurso, dando a los juicios escritos el carácter de verdades consagradas, y no de juicios emitidos por un mortal ${ }^{4}$. Es importante contrastar esa nueva forma de comunicación con el diálogo socrático, en el que cada sujeto habla para ceder la palabra al otro, y permitirle así pedir aclaración de lo que dice o pro-poner nuevas soluciones.

Lo que está en juego en la objeción que hace Platón al discurso escrito de Lisias, puede precisarse y tener un sentido para nosotros, a propósito del sujeto anónimo de "los medios de comunicación".

1. Platón usa justamente el medio que condena, justamente para condenarlo, en beneficio del diálogo.

2. Platón, Fedro, Madrid: Biblioteca Clásica Gredos, 1979

3. Se empezó a llamar "logógrafo" a quien escribía sus discursos.

4. Emisiones semejantes al "se dice" descrito por Heidegger en Ser y tiempo. 
La escritura, o en nuestro caso, la publicidad representativa, no puede — por imposibilidad estructural - cumplir la función debida a toda comunicación "corp-oral"s. Platón muestra, con diversos argumentos, que lo escrito carece del sujeto real, presente, que hace posible, sustenta y da sentido a toda comunicación oral.

Tratemos de explicitarlo ahora con el argumento básico que recorre el Fedro y que otorga hoy un renovado sentido al problema:

Toda proposición —oral o escrita - consta de un sujeto ${ }^{6}$ gramatical (explícito o tácito): la entidad de la cual se habla. Pero una cosa es el sujeto representado por la proposición y otra el sujeto presente en la comunicación, esto es, el sujeto actual que propone tal o cual vínculo a otros sujetos ${ }^{7}$.

¿Cuál es el grado de importancia metafísica que tiene todo esto?

Sin un sujeto que diga la proposición, esto es, que proponga algo a otro sujeto, por ejemplo, que "la tierra gira alrededor del sol" o que avise que "afuera está lloviendo" o que declare a alguien que "va a tomar medidas...", etc., no habría una razón de ser para decir lo que decimos. Hablar a otro sería el sinsentido de toda comunicación, modos de ser indescifrables desde el lenguaje. Afirmar, negar, preguntar, pedir, aconsejar, son modos de vinculación en virtud de los cuales convergemos hacia el mundo.

El sujeto que habla — para volver a nuestro ejemplo—: Copérnico cuando sostiene por primera vez que "la tierra gira alrededor del sol", cuando invalida lo que se decía con absoluta certeza en ese tiempo... se vincula a los seres humanos, cambiando su concepción del ser humano: de "el puesto del hombre en el cosmos".

Volvamos a Platón: fue el primero en comprender que lo que importa en una comunicación real es saber qué vínculo quiere establecer el que habla con el que escucha. Hablar es comunicarse modos reales de vinculación entre sujetos reales. El mundo —usando una exageración idealista - es un pre-texto9. La historia tiene algún sentido en virtud de la vinculación con la que los seres humanos convergen hacia un mundo que se crea en virtud de tal comunicación.

5. Corp-oral: en la que necesariamente participan como significantes tanto el cuerpo como los sonidos significantes.

6. Salvo las conocidas y misteriosas proposiciones impersonales: "llueve", "truena", etc.

7. Si no la dice actualmente nadie, es una comunicación meramente potencial.

8. Obra de Max Scheler.

9. Queremos decir analógicamente: "la materia prima" de la vinculación humana. 